\title{
Mechanism of public control of food products quality in Russia and in the Volgograd region
}

\author{
Elena V. Loginova \\ Volzhskiy branch, \\ Volgograd State University \\ Volzhskiy, Russia \\ elena.loginova@vgi.volsu.ru
}

\author{
Alla V. Litvinova \\ Volzhskiy branch, \\ Volgograd State University \\ Volzhskiy, Russia \\ litvinova_av@mail.ru
}

\author{
Tatiana A. Plaksunova \\ Volzhskiy branch, \\ Volgograd State University \\ Volzhskiy, Russia \\ plaksunova@vgi.volsu.ru
}

\begin{abstract}
In the article the problems of the control of the food products quality in Russia and in the Volgograd region are studied. The necessity of the development of the mechanism of the public control what will allow increasing the food products quality by means of the completion of the state control mechanism and consequently will increase the standard of living of the population of the country and of the region in particular.
\end{abstract}

Keywords - mechanism, public control, quality, food products, monitoring, region

\section{INTRODUCTION}

The development in Russia of the state and the public control was accompanied by the changes in the content, goals and targets. Gradually the priorities of the control determined by the necessity of the increase of the competitiveness of the country, encouragement of the industrial production development and the turnover in the internal and external market of Russia of competitive goods, works and services when adjusting them to international norms and the obligations of the country as the WTO members and the Eurasian economic union, by the increase of the life standard of the population and its trustfulness to the procedure and the results of control were formed. One of such priorities became the quality as an integrated and systematic notion used for present moment in case of a wide range of control objects: the goods, works and services. The notion of quality is also used for the control of the activity of federal executive authorities and of highest level authorities (responsible authorities of executive power) of the subjects of the Russian Federation, of the chief executives of territorial government non budgetary funds (their regional authorities), local self governing authorities, medical centers services, social security services and so on.

In the goods produced in the country the leading role as the objects of control have the food products which integrate the most important social and economic aspects of the functioning of every state. The social importance of this group of products is determined by the impossibility of the physical, intellectual and spiritual activity of a person without them. The intensity of consumption of food products is the most important indicator of the life quality of the population of the country. On the other hand the process of production, exchange and consumption considerably contribute to the creation of the material basis of the economic functioning of the state, they are a serious means of accumulation of incomes of the population, basis of the fiscal revenues into the budgets of various level and therefore directly influence the rate, dynamics and the balance and the efficiency of the economic growth. And, finally the production and consumption of food products become the basis of the provision of the food security of the country. At the same time the quality and consequently the competitiveness, provision of goods have a decisive role in the provision of all the social and economic process mentioned above.

The state (municipal) control (monitoring) of the quality of the goods produced and sold in Russia including the food products at the modern stage is implemented with the use of such tools as technical regulation, standardization, certification and conformity assessment. The peculiarities of the state (municipal) control or (monitoring) of food products for the present moment are determined by the fact that the given type of goods is not included into the list of products subject to obligatory certification. The state control of food products is mainly directed on the compliance with the safety requirements included into the technical guidelines. The voluntarily observed requirements of government standards for the consumer food products are confirmed by the producers in the form of the voluntarily certification.

Thus the scope of the activity of the state control bodies in respect to food products is extremely narrowed and is limited mainly by the compliance with the safety requirement. The control of food products parameters in the Russian practice is 
carried out as a rule at the violation of the consumer rights in case of their application into the organ which maintains federal supervision over the protection of consumer rights under the condition that the claimant appeals for the defense (restoration) of violated rights to a legal entity, self employed entrepreneur and in case when such an application was not examined or the requirements of the claimant were not satisfied. This situation in compliance with the article 10 of Federal Law dated December, 262008 № 294-FZ “About the protection of the rights of legal entities and individual entrepreneurs at the implementation of the state control (monitoring) and municipal control" is the basis for an unscheduled inspection for mentioned economic agents. When the powers of the bodies of the state control and monitoring in the sphere of safety and quality of food products and also the manifestations of unfair competition in the product market are sharply narrowed the mass consumer became practically unprotected in the relations with the producers and sellers.

The existing drawbacks of the state and municipal control (monitoring) over the quality of the good produced and sold in Russia including the food stuff are mainly connected with the canceling in 2016 the planned examination of the businesses. The relief from the planned examinations reflected on the activity of Rospotrebnadzor or the leading municipal inspector together with Rosstandard in the product market of the country. The system of the planned state and municipal control which existed until 2016 and which used in its work the tools did not allow fully converting the food market of the country into the market of safe and qualified food products and there are official statistical data for that. Thus in 2015, in the year which preceded the freezing of the business controls a considerable growth of the food products consumed by the population were observed. In particular in comparison with 2014 the share of the production of the Russian origin of a low quality or dangerous for human life and health (\% from the total volume of the inspected goods) grew for meat and poultry meat 3,4 times, for sausage products 4,5 times, for fish production 2 times, macaroni products 3 times, butter 1,5 times, beer 3,8 times (Table 1).

According to the results of 2016 (the first year of the freezing of the business controls) the share of the low quality, dangerous food product of the domestic origin which were checked by Rospotrebnadzor reduced for meat and poultry meat 1,6 times, fish products 4,9 times, noodle products 1,5 times, confectionary 1,8 times, vegetable oil 7 times.

The weakening of the presence of the low quality and dangerous products observed in 2016 is obviously explained not by the fundamental shifts in the production market of Russia but by the changes in the character of the control from the part of the state. In compliance with the Federal Law adopted December, 262008 № 294-FZ “About the protection of the rights of legal entities and individual entrepreneurs at the implementation of the state control (monitoring) and municipal control" the planned business examination are held only one time every three years.
TABLE I. QUALITY OF THE DOMESTIC AND IMPORTED GOODS IN THE CONSUMER MARKET IN 2000-2017

\begin{tabular}{|l|c|c|c|c|c|c|c|c|}
\hline \multirow{2}{*}{\begin{tabular}{c}
\multirow{2}{*}{$\begin{array}{c}\text { Food } \\
\text { products }\end{array}$} \\
\cline { 2 - 10 }
\end{tabular}} & \multicolumn{2}{|c|}{ Low quality or dangerous products, \% form the volume } \\
of the selected goods
\end{tabular}

Source of the information [1, p. 493; 2, p. 489; 3, p. 100; 4, p. 324]

After a two year experiment with the planned examination of the activity of the legal entities and self employed entrepreneurs the increase of the problems with the quality and safety of products consumed in the country including the food stuff is obvious. The comparison of the statistical data after the examinations of Rospotrebnadzor for January-September with the data for an analogous period of 2016 showed the growth of the volumes of the low quality products and dangerous food products. For instance this ratio for national goods grew for vegetable oil 10 times, for cheese 1,3 times. In the imported goods this index for meat and poultry meat grew 3 times, for sausage products grew 14 times, for canned meats, meat and vegetable conserves grew 43 times, for confectionary grew 24 times and so on [1, c.100].

The absence of the papers confirming the fulfillment of requirements for marking, conditions of conservation, expiry date exceeding are the main reasons of a low quality and danger of domestic food products. After the fist half of year 2017 the leaders of the low quality and dangerous food products in compliance with the reasons mentioned above became meat and poultry meat, sausage products, fishery products, cheese, bread and flower products.

The problem of the counterfeiting of the quality of the food products, its incompliance of its real state to the declared one remains acute. The most widely spread is the situation with the unconfirmed declaration of the fulfillment of the requirement of government standards. This problem exists in all the goods segments of the product market and is especially severe for vodka, liqueur and spirits, juice, mineral water, sausage products, milk and dairy products.

Generally it can be said that rigid normative requirements of the state control bodies, weakening of the control over the 
businesses, absence of an adequate system of measures capable of reimbursing the damage, absence of responsibility for the production and realization of the low quality and dangerous food products which do not ensure fully the efficiency of the state and municipal control (monitoring) in the product market have lead to the situation in the country. In this case it is necessary not only to improve the state control, to introduce economically founded sanctions proportional to the made violations but also to develop fully the public control of the quality of the produced and sold food products.

\section{MATERIALS AND METHODS}

The main advantages of the public control consist in the opportunity to involve first of all the general public into the monitoring of the quality and food products safety at the existing amount of budgetary expenses and secondly to control those quality parameters for which the powers of state authorities are absent or are maximally narrowed.

In order to exercise the advantages mentioned above the development of the institutional mechanism of the public control of the quality of the food products which will become a specific factor of its productivity growth is indispensable.

The system approach to the analysis of the institutional mechanism of the public control of the food products quality adequate to modern imperatives of the development of the Russian society determines the necessity of taking into account the following basic principles of its creation. The development of the mechanism is expected to be carried out on the basis of the use of the potential existing in the corresponding institutes, forms and instruments of the quality control and in the development of new institutional forms of its realization. At the creation of the institutional mechanism of the public control the quality of food products it is indispensable to take as priority of the routine mechanism (following the sustainable behaviourial stereotypes) completed by the elements of the legal mechanism (activity on the basis of formal norms) as the realization of the control functions is implemented on the basis of the self organization of citizens and their of associations which determine the objects of control at a possible correction of the goals of the control from the part of the state as an institute of the coordination of the interests at the choice of the strategy of social and economic development.

The main elements of the institutional mechanism are:

- subject and object, structural and functional interaction of the economic actors;

- unity of integral and differentiated goals, methods, means, forms and results of actions;

- blocks of formation, interiorization, monitoring and correction of institutional requirements in the newly created institutes [5].

It is necessary to take as subjects of institutional mechanism the citizens, their associations, the state and also various business organizations.
From the point of view of the characteristics of the functional properties these subjects (actors) can be divided into the following groups:

- «initiators» of control (citizens and their associations, business organizations and the state);

- «realizers» of control (citizens and their associations);

- «coordinators» of control (citizens and their associations and the state).

The process of the interaction between subjects within the institutional mechanisms is determined by the functions attached to it:

- bearing in mind the necessities of the society determined by the specificity of the stage of social and economic development, the state creates the encouragement for their realization («control initiating») and also provides the normative formalization of the control process, the monitoring of its realization and if necessary corrects the institutional requirements for control («control coordination»);

- when pursuing local goals (for instance the increase of the competitiveness of the produced goods, creation of a favourable image in the opinion of potential consumers) the business organizations "initiate" the public control of the quality;

- when trying to maximize the degree of the satisfaction of the consumption of food products the citizens and their associations «activate» the quality control, «realize» it by means of the use of the corresponding tools and interiorize the requirements for the control («control coordination»).

Thus the methodological approach to the development of the institutional mechanism of the public control of the quality of food products promising the achievements in the sphere of the institutionalism and the theory of management by the quality of the food products consists in the following provisions. The model of the institutional mechanism of the public control of the quality of food products is expected to reflect the process of the interaction of its subjects within the specific social and economic conditions and at the presence of corresponding institutional rights and limitations.

\section{RESULTS AND DISCUSSION}

A. Structural and functional characteristic of the main subjects of the institutional mechanism of the public control of the quality of food products can be presented in the following way:

\section{- $\quad$ Government (state) subjects.}

The federal body of executive power realizes the functions of state control in the sphere of technical regulation and standardization including the food products is the Federal agency for technical regulation and metrology (Rosstandart) and its territorial organs implement the control over other federal organs of executive power, organs of executive authority by the subjects of the Russian Federation, local authorities, non governmental associations and other organizations. Together with Rosstandart the functions of the state and municipal control in the food market of the country are carried out by the Federal Service for survey in the sphere of the consumer rights and human well being (Rospotrebnadzor). In the Volgograd region these functions 
are carried out by the Administration of Rospotrebnadzor in the Volgograd region.

The main goals of the government subjects solved by them within the implementation of the control functions of the food products quality are the goal setting of the social and economic development, creation of legal bases of the public control, monitoring when needed and the correction of its implementation, also it is the decision making and the realization of the managerial solutions directed on the regulation effect when finding the food products of a low quality.

According to the Decree of the President of the Russian Federation adopted May, 72012 № 596 «About long term state economic policy» the target goals of social and economic development of the Russian Federation until 2020 are a transfer to an innovative socially oriented and competitive economy what in its turn implies the creation of the conditions for the increase of the life standard of the population which is impossible without the increase of the quality of the consumed food products.

The basis of the normative acts of the public control of quality and safety of food products in the consumer market of the country are the Law of the Russian Federation adopted February, 71992 № 2300-1 «About the protection of consumer rights», Federal Law adopted May, 191995 № 82FZ «About public associations » and the Federal Law adopted June, 212014 № 212-FZ «About the bases of the public control in the Russian Federation».

In the Volgograd region the following system of normative and legal acts in the sphere of public control exists. In particular they are Law of Volgograd region «About the implementation of the control of Volgograd region» adopted December, 302015 № 240-OD, Law of Volgograd region «About the Public Chamber of Volgograd region» adopted March, 142008 № 1647-OD. For the pubic control of the activity of the executive powers of the Volgograd region the Decree of the Government of the Volgograd region dated June, 232014 № 316-n «About the order of determining the level of informative openness of the organs of executive power in the Volgograd region» is adopted. For the crime prevention in the sphere of the municipal improvement the Decree of the Volgograd regional administrative commission adopted May, 312013 № 11-20/13-34 «About public trust line "Public control" in case of crime prevention in municipal improvement» was passed. It was further developed in the decrees of local legislators. However the normative documents which determine the peculiarities of the public control of quality and safety of food products produced and sold in the Volgograd region are absent in the normative base of the region.

The state subjects on the basis of the accumulation of the data obtained in the result of the public control of the quality of food products carry out the monitoring of the quality. The violation of the requirements for food products according to the Article 14.4 «Code of Russia about Administrative crimes» leads to the administrative fine imposition (for sole proprietors it is 10-20 thousand rubles, for organizations it is 20-30 thousand rubles; at a second law violation it is $15-30$ thousand rubles and 30-50 thousand rubles correspondingly) or the suspension of operations up to 90 days.

\section{- $\quad$ Citizens and their associations.}

Despite the fact that according to Article 3 of Federal Law № 212-FZ «About foundations of the public control in the Russian Federation» the citizens have the right to participate in the implementation of public control they as a rule exercise their rights in public associations and other non governmental non commercial organizations.

The goals of the unions of the citizens in the implementation of the functions of the public control of the quality of food products are:

- participation in the development of obligatory requirements for the goods (works, services) and also in the projects of laws and other normative and legal acts of the Russian Federation regulating the relations in the sphere of consumer rights protection;

- independent quality expertise, control of the safety of goods (works, services) and also the compliance of the consumer properties of goods (works and services) to the quality declared by sellers (producers, workers) in the information about them;

- public control exercise for the observance of consumer rights;

- forwarding into the body of state control and into the organs of local self administration the information about the facts of the consumer rights violation for the examination of these facts and in this case taking measures in order to stop the consumer rights violations;

- participation in the expertise of the facts of consumer rights violation in case of the complaints of consumers;

- information dissemination about the consumer rights and the necessity of actions in the protection of the rights, about the results of comparative research of the food products quality.

According to the data of the Ministry of Justice of the Russian Federation in 2016 the number of the registered public associations which set as a goal the task of the protection of the consumer rights made up 1864 what was $6 \%$ higher than in 2015 or $14 \%$ higher than in 2014 [6].

The example of the successfully functioning subjects of the public control of quality and safety of food products in the consumer market can become the non governmental association «Russian association of public control» created in 2014. It is also the association of the consumers of Russia which both since 2014 the general partners of the project "Quality mark" whose main goal is to stop the work of the organizations producing low quality and dangerous for health goods and services sold in Russia by means of public control. These are in first turn food products, corruption and criminal practice in the consumer market. Another non governmental organization established in 2014 is "Roskachestvo" which implements the monitoring of the quality of all groups of consumer goods including the food products.

According to the data of the Committee for Industry and Commerce of the Volgograd region in the territory of the region there exist 15 public associations of consumers dealing 
with the consumer rights protection which were registered in the Ministry of Justice of the Volgograd region. Among them there is the Volgograd public movement of the consumer rights protection which is responsible for the public control over consumer rights, monitoring of the quality of food products by means of the program "Quality from the producer to the seller" which was established in 1995 and today it is the organizer of the yearly contest «Volgograd quality mark "Public esteem"». An important role in the exercising the public control in the regional consumer market also have the Volgograd regional non governmental organization of the consumer rights and tax payer rights protection "People rights", regional non governmental organization "Society for consumer rights protection of the Volgograd region" and the Volgograd region non governmental organization for the consumer rights protection "Consumer control".

B. The institutional mechanism of the public control over the quality of the food products at the regional level is characterized by the following stages [7]:

- The object of the public control is determined coming from the goals set for the social and economic development of the country (region) or from the goals of citizens and local associations.

- The subjects interested in the exercise of the public control and in compliance with the existing laws determine the scope of their powers and functions.

- The subjects of the public control of quality join their resource potentials by means of creating the conditions for the control measures.

- The process of the organization of the public control takes place which includes the clarifying of its content, structure, character of the interaction of the subjects and the distribution of powers between them and also the description of the decision making process.

- The whole complex of the methods of public control is determined and the corresponding tools are chosen.

- The process of the immediate use of the tools of the public control is described and the result of which is the assessment of the food products quality.

- On the basis of the fulfilled assessment the managerial decisions directed on the growth of the quality of food products are taken. (Figure 1).

C. The implementation of the suggested institutional mechanism of the public control of food products quality is expected to be carried out by means of the following tools together with the previously used:

- The development of the volunteer initiative what implies the creation of non formal associations which can also become the subjects of the public control of the quality. The use of the volunteers will allow increasing not only the involvement of the citizens into the system of the public control but also will allow improving the resource base for its implementation as in Russia today the grants for volunteer programs are allocated.

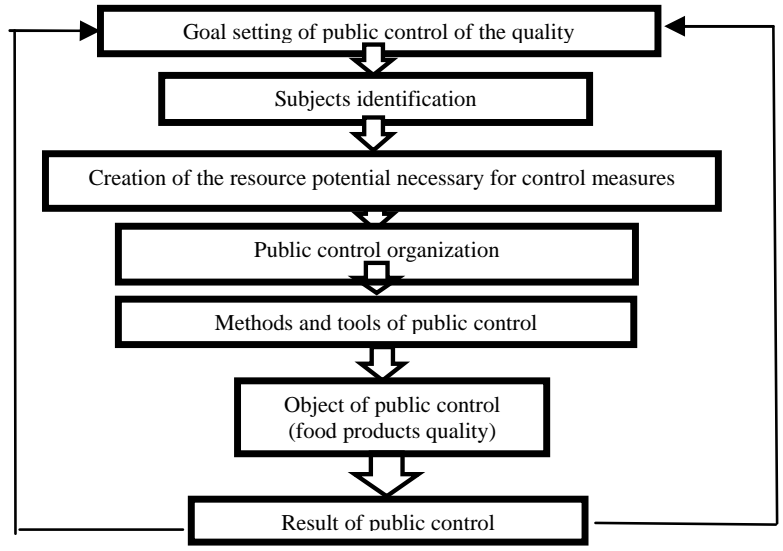

Fig.1. Stages of the mechanism of the realization of the public quality control of food products.

- $\quad$ The informing of citizens about the goals and results of public control and also the opportunities to take part in it takes place by means of the Internet what will increase the transparency of the control measures and also of managerial decision taken according to the results.

- The organization of the interactive dialogue via social nets what will allow accelerating the process of the unification of the citizens for the problem determination in provision of the food products quality and also will allow encouraging the participation in their solution.

- The creation in the Internet of specialized platforms for the accumulation of the claims of citizens and of organizations of the business about the quality of food products and about the inertness of the institutes of state control of the quality in case of producers (sellers) of inappropriate quality.

- $\quad$ The collaboration of state institutes, citizens and their associations will allow optimizing the state participation in the quality control and will encourage the involvement of the citizens into this process what will increase the openness and the transparency of the quality control.

\section{CONCLUSION}

For the development of the public control of quality and safety of food products it is necessary to take specific practical measures in all the scope of the problems accompanying the process.

A. Firstly, the country does not possess the official statistical base about the results of the public control of the quality and safety of food products. It is necessary to create an informational system open to general use and which will contain the data about the results of control in case of various groups of food products of industrial and commercial associations, regions of Russia, information about the violators who sold dangerous and low quality goods and also the information about the responsibility for their actions. The creation of such system will increase not only the awareness of the consumers but also the responsibility of producers and the sellers working in the food product market of Russia. 
B. Secondly, it is indispensable to include into the list of the subjects of control the persons with the status "public inspector" working either independently or presenting non profit organizations of consumers.

C. Thirdly, the use of the suggested tools of the public control of the quality of food products will allow increasing its transparency and openness and consequently its productivity.

\section{Acknowledgment}

The authors express gratitude to the Russian Fund for Fundamental Research and to the Administration of the Volgograd region for the support of the project № 17-1234024 «Integral model of the assessment of the implementation of public administration in the regions of Russia (on the example of the Volgograd region)».

\section{References}

[1] Rossiiskii statisticheskii ezhegodnik 2015: Stat. sb. [Russian statistical bulletin 2015: collection of articles. Rosstat]. Moscow: Rosstat Publ., $2015,728 \mathrm{p}$.
[2] Rossiiskii statisticheskii ezhegodnik 2016: Stat. sb. [Russian statistical bulletin 2016: collection of articles. Rosstat]. Moscow: Rosstat Publ., 2016, 725 p.

[3] Sotsial'no-ekonomicheskoe polozhenie Rossii. Yanvar'-oktyabr' 2017 g. Stat. sb. Rosstat. [Social and economic position of Russia. JanuaryOctober 2017. Collection of articles. Rosstat]. Moscow: Rosstat Publ., 2017, 426 p.

[4] Rossiya v tsifrakh. 2017: Krat.stat.sb.Rosstat. [Russia in figures. 2017. Short statistical bulletin. Rosstat]. Moscow: Rosstat Publ., 2017, 511 p.

[5] Lebedeva N.N. Institutsional'nyi mekhanizm ekonomiki i ego transformatsiya $\mathrm{v}$ Rossii : Dis. ... d-ra ekon. nauk : 08.00.01 [Institutional mechanism of economy and its transformation in Russia. The thesis for the scientific degree of the doctor of economic sciences: 08.00.01]. Volgograd: Izd-vo Volgu Publ., 2002, 385 p.

[6] Zashchita prav potrebitelei v Rossiiskoi Federatsii v 2016 godu: Gosudarstvennyi doklad [Consumer rights protection in the Russian Federation in 2016: State report]. Moscow: Federal Service for Control of Consumer Rights and Human Well Being Publ., 2017, 283 p.

[7] Loginova E.V., Loseva N.V., Polkovnikov A.A., Kalinin A.P. Otsenka realizatsii publichnogo upravleniya $\mathrm{v}$ regionakh Rossii na osnove matematicheskikh metodov modelirovaniya [Assement of the implementation of public administration in the regions of Russia on the basis of the methods of mathematical modelling]. Regional'naya ekonomika i upravlenie: elektronnyi nauchnyi zhurnal [Regional economics and management: electronic scientific journal]. ISSN 19992645, №3 (51), Article number: 5106. Date of publication: 2017-08-22. Available at: http://eee-region.ru/article/5106/ 